\title{
Eastern Filbert Blight Resistance in Hazelnut Accessions 'Culplà', 'Crvenje', and OSU 495.072
}

\author{
Brooke C. Colburn ${ }^{1}$, Shawn A. Mehlenbacher ${ }^{2,4}$, Vidyasagar R. Sathuvalli ${ }^{2}$, and David C. Smith ${ }^{3}$ \\ Department of Horticulture, 4017 Agricultural and Life Sciences Building, Oregon State University, \\ Corvallis, OR 97331
}

\begin{abstract}
AdDitional INDEX words. Corylus avellana, Anisogramma anomala, microsatellite, simple sequence repeat, linkage map
Abstract. European hazelnut (Corylus avellana L.) is a significant crop in Oregon, where 99\% of United States hazelnuts are produced. Eastern filbert blight (EFB) caused by Anisogramma anomala (Peck) E. Müller is an important disease that infects the trees, reduces yield, and causes premature death. Managing the disease through cultural methods and fungicide applications is laborious and expensive, and genetic host resistance is considered the most viable option for control. Genetic resistance from 'Gasaway' has been used to develop resistant cultivars including Yamhill and Jefferson, but concern about the durability of this single resistance gene stimulated a search for additional sources of resistance. This study used three recently identified sources of EFB resistance: 'Culplà' from Spain, 'Crvenje' from Serbia, and OSU $\mathbf{4 9 5 . 0 7 2}$ from southern Russia. RAPD markers linked to resistance from 'Gasaway' were absent in all three accessions. Disease response was noted in segregating progenies following greenhouse or structure inoculation, and the resistance loci were mapped using microsatellite markers. In only four of the nine progenies did segregation for disease response fit the ratio of 1 resistant: 1 susceptible expected for a single locus, a heterozygous resistant parent, and a dominant allele for resistance. Three progenies showed an excess of resistant seedlings while two showed a deficiency of resistant seedlings. The reciprocal translocations reported in several leading hazelnut cultivars may be present in the parents of the studied progenies, and affecting the segregation ratios. Microsatellite marker A614, previously mapped to linkage group (LG) 6, was closely linked to resistance from all three sources. Maps were constructed for LG6 for each resistant parent using microsatellite markers. The three resistance loci mapped to the same region on LG6 where resistance from 'Gasaway' and OSU 408.040 are located. The resistance alleles in all five accessions may be the same, or more likely are a cluster of different resistance genes in the same region. Markers LG628, LG610, and LG696 will be useful to breed new hazelnut cultivars with resistance from Culplà, Crvenje, and OSU 495.072.
\end{abstract}

European hazelnut is an important crop in Oregon's Willamette Valley, where the trees thrive in the mild, Mediterranean climate. Hazelnut is the 12th most valuable commodity in the state [U.S. Department of Agriculture (USDA), 2013], and 99\% of all commercial hazelnut production in the United States is in Oregon (Mehlenbacher and Olsen, 1997). Hazelnuts are valued for their high quality kernels that have excellent flavor and high oil content, and are ideally suited for use in confections and chocolates (USDA, 2011). Hazelnuts also contain compounds with purported anticancer properties and reduce the risk of coronary heart disease in consumers (Richardson, 1997). Hazelnuts have been grown commercially in Oregon since the early 1900s. Eastern filbert blight was discovered in the Willamette Valley in 1986 where it posed a serious threat to the industry's existence. With new plantings of EFB-resistant cultivars, the number of hectares planted to hazelnuts has increased sharply in the last 5 years, while older orchards of Barcelona and Ennis are removed when they are heavily diseased and no longer productive.

\footnotetext{
Received for publication 15 Dec. 2014. Accepted for publication 29 Jan. 2015. A technical paper of the Oregon Agricultural Experiment Station.

Funding from the Oregon Hazelnut Commission, State of Oregon, and Hatch Act, and a specific cooperative agreement with the U.S. Department of Agriculture is acknowledged and appreciated.

${ }^{1}$ Former graduate research assistant. Current address: 4640 S. Utica Street, Denver, CO 80236.

${ }^{2}$ Former post-doctoral research associate. Current address: Hermiston Agricultural Research and Extension Center, 2121 S. First Street, Hermiston, OR 97838. ${ }^{3}$ Senior research assistant

${ }^{4}$ Corresponding author. E-mail: Shawn.Mehlenbacher@oregonstate.edu.
}

The pathogen Anisogramma anomala causes the disease EFB on susceptible trees of C. avellana. This fungus is endemic to the eastern North America and infects only Corylus L. species. It is only present in North America. Many C. americana Marsh. selections are resistant to, or tolerant of, the pathogen (Capik and Molnar, 2012; Muehlbauer et al., 2014), but infections are usually much more severe on european hazelnut (Pinkerton et al., 1993). The life cycle of $A$. anomala is well documented (Gottwald and Cameron, 1979; Johnson et al., 1996; Pinkerton et al., 1992, 1998a, 1998b; Stone et al., 1992). The fungus has a 2-year life cycle that begins with ascospore release from perithecia in the early fall to late spring during prolonged periods of branch wetness. The spores are disseminated by wind or water, and host tissue is susceptible to infection during spring and early summer. The ascospores germinate and produce hyphae that directly penetrate young growing shoots, permeate and destroy the cambial layer, and produce visible cankers with stromata $12-16$ months after infection. Infection results in stem cankers, girdling and death of branches, reduced yield, and premature tree death. Disease prevention on susceptible genotypes is difficult. Control measures involve scouting and pruning out diseased limbs and multiple fungicide applications during the spring.

Genetic host resistance has been used in many crops to impede disease development. The planting of disease-resistant cultivars results in significant economic savings to growers in terms of reduced pesticide costs and the potential for increased yield. Because of the cost and difficulty of managing A. anomala with pruning and spraying, genetic host resistance is considered the most viable option for managing EFB (Mehlenbacher, 1995). 
Selections of $C$. avellana have been found that exhibit qualitative or quantitative resistance to EFB (Capik and Molnar, 2012; Capik et al., 2013; Chen et al., 2005, 2007; Lunde et al., 2000, 2006; Mehlenbacher et al., 1991; Muehlbauer et al., 2014; Sathuvalli et al., 2010, 2011a, 2011b, 2012). 'Gasaway' was the first $C$. avellana cultivar observed to express a very high level of resistance to EFB (Cameron, 1976). The resistance is conferred by a dominant allele at a single locus (Mehlenbacher et al., 1991). The Oregon State University (OSU) hazelnut breeding program has combined 'Gasaway' resistance with other desirable traits, and a series of new cultivars and pollenizers has been released (Mehlenbacher et al., 2007, 2009, 2011, 2012).

Recently released cultivars with Gasaway resistance, including Yamhill and Jefferson, are being widely planted in Oregon. However, resistance genes are vulnerable to "breakdown" over time as new isolates of the pathogen arise or are introduced (McDonald and Linde, 2002). Accessions expressing very high resistance in Oregon have been screened in New Jersey, where $A$. anomala is native and disease pressure is high, and EFB cankers with stromata have been observed on some trees, including 'Gasaway' (Molnar et al., 2010; Capik and Molnar, 2012). In Oregon, under high disease pressure, small cankers have been observed on 'Jefferson', 'McDonald', and a few other genotypes that carry the 'Gasaway' resistance gene (S.A. Mehlenbacher, unpublished).

In light of the potential for breakdown of 'Gasaway' resistance, it is desirable to identify diverse sources of resistance and use them in breeding. Ideally, multiple resistance genes could be combined in a single selection. This pyramiding of disease resistance genes is intended to reduce the likelihood that the pathogen can mutate and simultaneously overcome the different resistance genes. The pyramiding of major resistance genes has been used successfully in several crops, including apple (Malus $\times$ domestica Borkh.) for resistance to scab caused by Venturia inaequalis (Cke.) Wint. (Kellerhals et al., 2009) and rice (Oryza sativa L.) for resistance to bacterial blight caused by Xanthomonas oryzae Ishiyama pv. oryzae Swings et al. (Huang et al., 1997). In barley (Hordeum vulgare L.), resistance to stripe rust incited by Puccinia striiformis Westend. f. sp. hordei Erikss. is conferred by quantitative trait loci (QTL), each of which confers a degree of resistance. Pyramids of two or three resistance QTL in 'Baronesse' background showed reduced lesion size and pustule density (Richardson et al., 2006).
Many types of markers have been investigated in hazelnut, including random amplified polymorphic DNA (RAPD), amplified fragment length polymorphism (AFLP), and microsatellite, the latter also known as simple sequence repeat (SSR) markers (Chen et al., 2005; Davis and Mehlenbacher, 1997; Mehlenbacher et al., 2004; Sathuvalli et al., 2011a, 2011b, 2012). The RAPD markers $152_{800}$ and $268_{580}$ are routinely used in marker-assisted selection (MAS) for EFB resistance from 'Gasaway' (Davis and Mehlenbacher, 1997; Mehlenbacher et al., 2004). MAS was implemented in the OSU hazelnut breeding program because it allowed identification of resistant seedlings in the absence of the pathogen and bypassed the 16-month latent period for canker development. Scoring of disease response remains problematic, as susceptible genotypes occasionally escape infection in both greenhouse and structure inoculations, and resistant selections occasionally develop small cankers under high disease pressure.

More than 330 SSR markers have been developed for hazelnut (Bassil et al., 2005; Boccacci et al., 2005; Gürcan and Mehlenbacher, 2010; Gürcan et al., 2010; Peterschmidt, 2013; Sathuvalli and Mehlenbacher, 2013), and most have been placed on the linkage map of Mehlenbacher et al. (2006) where they serve as "anchor loci." With SSR anchor loci, additional EFB resistance loci can be assigned to linkage groups (LGs) and align maps from different progenies. EFB resistance from 'Ratoli' maps to LG7 (Sathuvalli et al., 2011a) and from Georgian OSU 759.010 maps to LG2 (Sathuvalli et al., 2011b), while resistance from OSU 408.040 maps to the same location as 'Gasaway' resistance on LG6 (Sathuvalli et al., 2012).

This study investigated disease response in progenies segregating for EFB resistance from three sources: 'Culplà', 'Crvenje', and OSU 495.072. In addition, the resistance loci were mapped.

\section{Materials and Methods}

Plant materials. The three EFB-resistant hazelnut accessions used in this study were 'Culplà', 'Crvenje', and OSU 495.072. 'Culplà' is a Spanish cultivar received as scions from IRTA Mas Bove in Reus, Spain. It is believed to have originated in Tarragona, and molecular studies placed it in the SpanishItalian group where it shows a close relationship to 'Tonda Gentile delle Langhe' from Piemonte, Italy and 'Sant Pere'

Table 1. Ten hazelnut progenies used to study segregation for susceptibility to eastern filbert blight.

\begin{tabular}{|c|c|c|c|c|c|c|}
\hline \multirow[b]{2}{*}{ Progeny } & \multirow[b]{2}{*}{ Parents (female $\times$ male $)$} & \multicolumn{2}{|c|}{ Inoculation method (no. seedlings) } & \multicolumn{3}{|c|}{ Seedlings (no.) } \\
\hline & & Structure & Greenhouse & With disease scores & With DNA & With both \\
\hline 01035 & OSU $713.068 \times$ OSU 495.072 & 0 & 112 & 112 & 112 & 112 \\
\hline 02020 & OSU $495.072 \times$ OSU 651.011 & 0 & 14 & 14 & 0 & 0 \\
\hline 05024 & OSU $675.028 \times$ Culplà & 37 & 80 & 117 & 117 & 117 \\
\hline 06027 & OSU $675.028 \times$ Crvenje & 123 & 116 & 239 & 157 & 157 \\
\hline 06028 & Crvenje $\times$ OSU $\times 79.114$ & 115 & 109 & 224 & 68 & 68 \\
\hline 09030 & OSU $1136.051 \times$ OSU 1041.069 & 69 & 0 & 69 & 0 & 0 \\
\hline 09031 & OSU $1154.027 \times$ OSU 1029.039 & 52 & 0 & 52 & 0 & 0 \\
\hline 09032 & OSU $1154.027 \times$ OSU 1039.051 & 23 & 0 & 23 & 0 & 0 \\
\hline
\end{tabular}

${ }^{\mathrm{z}}$ Structure inoculation by exposure of potted trees under a structure topped with diseased branches as described by Mehlenbacher et al. (2008) and based on Pinkerton et al. (1993). Seedlings are individual trees so there is no replication.

${ }^{\mathrm{y}}$ Greenhouse inoculation as described by Sathuvalli et al. (2011a). 
from Spain (Boccacci and Botta, 2010; Gökirmak et al., 2009). 'Culplà' was screened for resistance to EFB by Chen et al. (2007), who found no signs of infection following greenhouse inoculation. In 2005, 'Culplà' was crossed with susceptible parents OSU 675.028 and OSU 612.015, generating 117 seedlings in progeny 05024 and 92 seedlings in progeny 05023 , respectively (Table 1, Fig. 1).

'Crvenje', the second accession used in this study, was received as scions from the Fruit Research Institute in Čačak, Serbia. 'Crvenje' was screened for resistance to EFB in greenhouse inoculations and found to be completely resistant (Sathuvalli et al., 2010). In 2006, 'Crvenje' was crossed with susceptible parents OSU 675.028 and OSU 679.114, generating 239 seedlings in progeny 06027 and 224 seedlings in progeny 06028, respectively (Table 1, Fig. 1).

The third EFB-resistant accession, OSU 495.072, was selected from a group of seedlings grown from seeds sent in 1989 from the N.I. Vavilov Research Institute of Plant Industry in St. Petersburg, Russia. It is believed that the seeds were from a cultivar collection in southern Russia (S.A. Mehlenbacher, unpublished). OSU 495.072 has been screened for resistance to EFB in Oregon and New Jersey and has remained free of disease symptoms in both environments (Capik and Molnar, 2012; Molnar et al., 2010; Sathuvalli et al., 2010). OSU 495.072 was crossed with two susceptible parents-OSU 713.068 in 2001 and OSU 651.011 in 2002 , generating 112 in progeny 01035 and 14 seedlings in progeny 02020, respectively (Table 1, Fig. 1). In 2009, two resistant selections (OSU 1136.051 and OSU 1154.027) from the first set of crosses were used as parents to generate four additional seedling populations (Table 1, Fig. 1). OSU 1136.051 is a seedling from a cross of OSU $713.068 \times$ OSU 495.072, and OSU 1154.027 is from a cross of OSU $495.072 \times$ OSU 651.011 .

Greenhouse inoculations. Scions were collected from the seedling populations in the field in the winters of 2008, 2010, and 2011. Scions were stored at $-1{ }^{\circ} \mathrm{C}$ until they were grafted in April and May. Three replicates of each seedling were grafted onto rooted layers, and potted in $5-\mathrm{L}$ pots containing a medium composed of equal volumes fine bark of douglas fir [Pseudotsuga mezesii
(Mirb.) Franco], pumice, and peat and $9 \mathrm{~g}$ of $17 \mathrm{~N}-2.6 \mathrm{P}-10 \mathrm{~K}$ fertilizer (Sierra 3-4 month release; Scotts, Marysville, $\mathrm{OH}$ ). The trees were grown in the greenhouse under $24{ }^{\circ} \mathrm{C}$ days and $18{ }^{\circ} \mathrm{C}$ nights until the plants were growing vigorously and had developed 4-5 nodes. The inoculation chamber was constructed of a frame of PVC tubing $(1.27 \mathrm{~cm}$ diameter) and covered with $0.1-\mathrm{mm}$
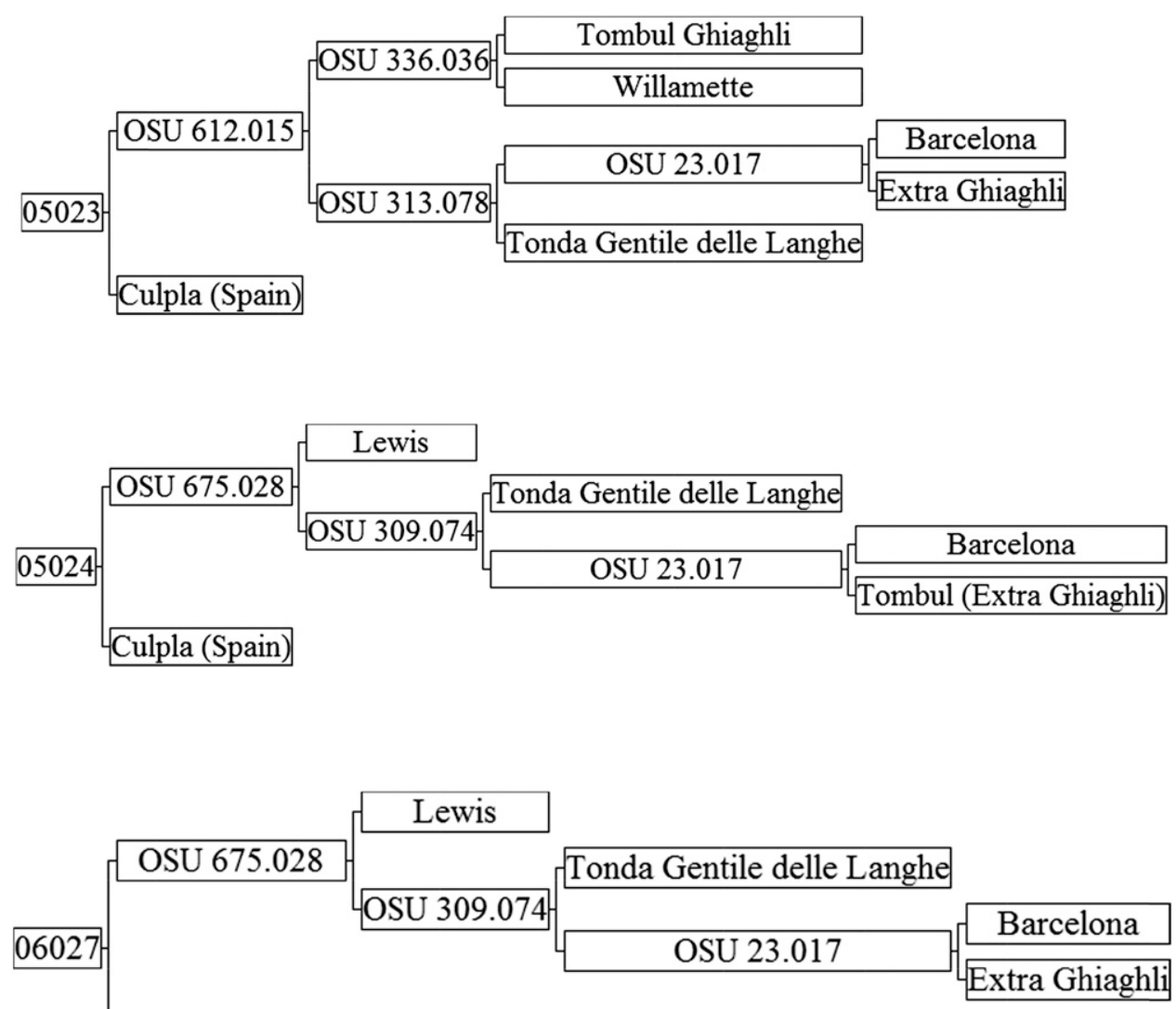

\section{Crvenje (Serbia)}

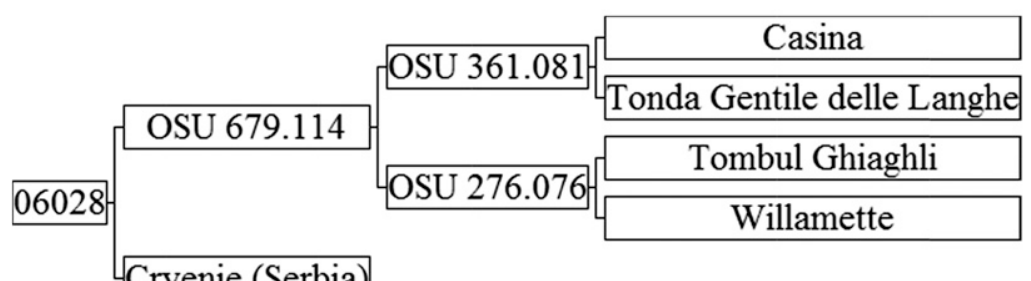

Crvenje (Serbia)

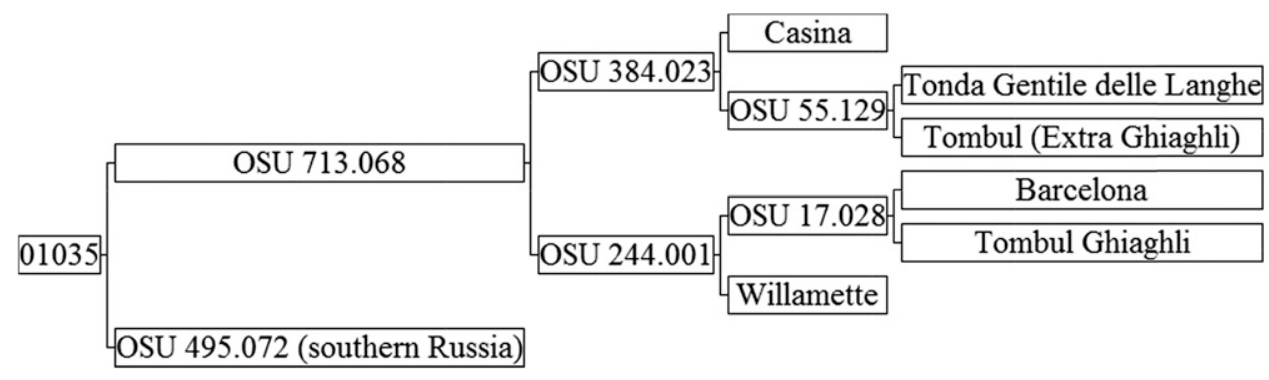

Fig. 1. Pedigrees of nine hazelnut progenies segregating for resistance to eastern filbert blight. 

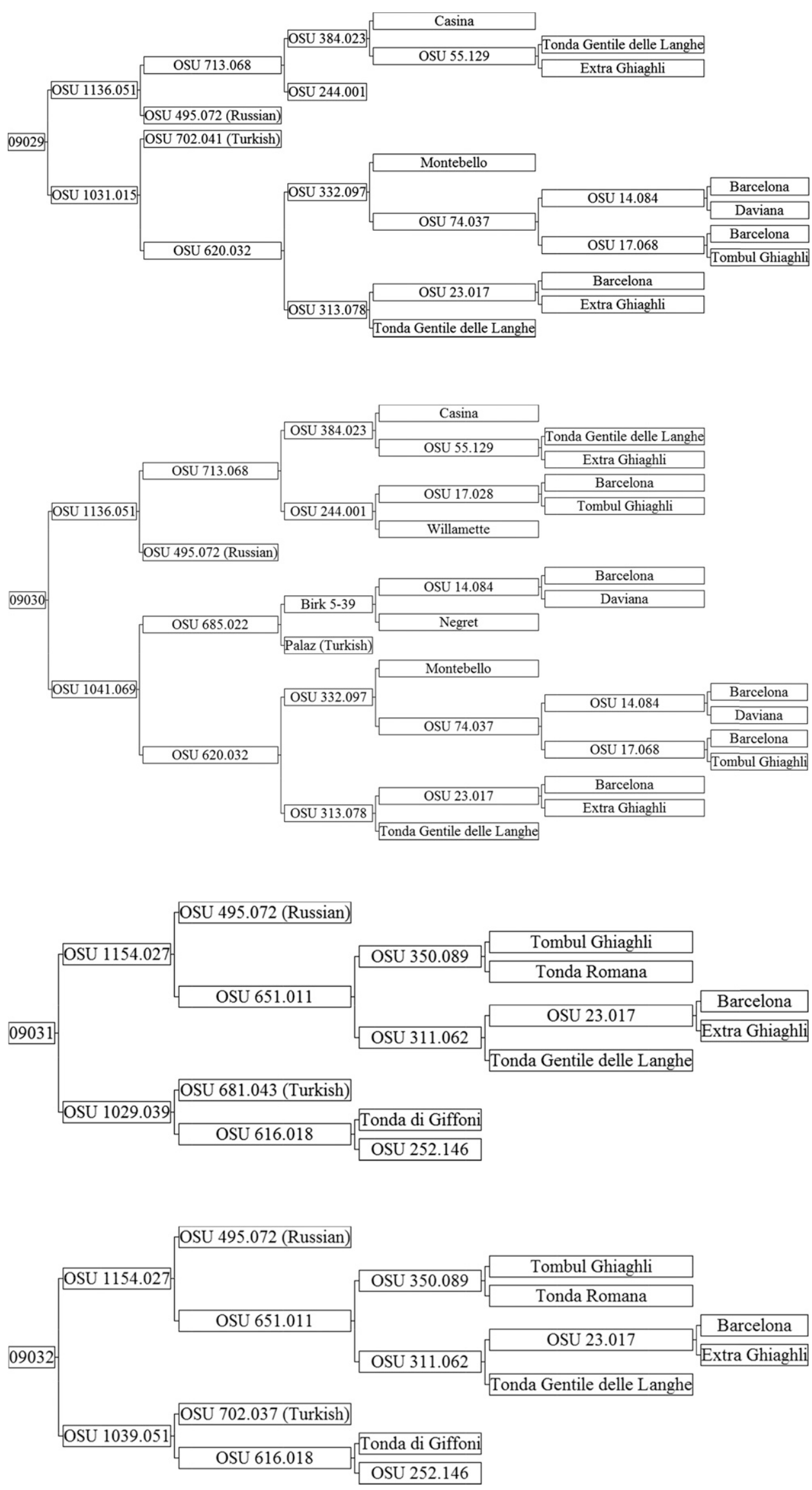

Fig. 1. (Continued) polythene sheeting on the walls, with the roof remaining open. The chamber spanned three greenhouse benches each measuring $2.44 \times$ $0.88 \mathrm{~m}$. A misting system was placed above the chamber. Three misters per bench $\left(7.57 \mathrm{~L} \cdot \mathrm{h}^{-1}\right)$ spaced $0.3 \mathrm{~m}$ apart were mounted $0.9 \mathrm{~m}$ above each benchtop. The misters were programmed with an automated unit (model No. DE 8 PR2; Davis Engineering, Canoga Park, CA) to run for $10 \mathrm{~s}$ every $30 \mathrm{~min}$ during the day ( 0800 to $1900 \mathrm{HR}$ ) and $10 \mathrm{~s}$ every hour during the night (1900 to $0800 \mathrm{HR}$ ). Diseased wood with cankers bearing mature stromata were collected from the OSU Smith Horticulture Research Farm in December annually and stored in polyethylene bags at $-20{ }^{\circ} \mathrm{C}$ until the following summer when they were used for greenhouse inoculations. Stored inoculum was removed from the freezer and thawed at room temperature. Perithecia containing ascospores were removed from the shoots using a spatula and ground in a mortar with a pestle and a small amount of water to release the spores. Water was added to bring the spore suspension to $100 \mathrm{~mL}$, the concentration was measured using a hemacytometer (Fisher Scientific, Hampton, $\mathrm{NH}$ ), and the suspension diluted to a concentration of $1 \times 10^{6}$ spores $/ \mathrm{mL}$. Inoculations were performed once per day either in early morning (0700 HR) or late evening (2000 HR) at 3-d intervals for a total of two inoculations. The inoculations were conducted during the cool hours of the day to increase the success rate and minimize the number of escapes. A spray bottle was used to apply the spore suspension to the one or two most vigorous shoot tips on each tree. Each shoot tip was sprayed until it was wet. Three days following the second inoculation, the trees were removed from the inoculation chamber, placed on benches, and grown for 3-6 months under the greenhouse conditions described previously. Seedlings were inoculated in the greenhouse in 2008, 2010, and 2011. 'Ennis' (highly susceptible) and 'Tonda di Giffoni' (high quantitative resistance) were included as controls. After growing for 3-6 months in the greenhouse, the inoculated trees were planted in a nursery row at the OSU Smith Horticultural Research Farm in 
Corvallis. The trees were scored for presence or absence of disease between October and November, 14-16 months after inoculation. Genotypes exhibiting cankers and stromata were scored as susceptible, and genotypes were scored as resistant if all three replications of the genotype were free from infection. If at least one replicate of a genotype exhibited disease symptoms, the genotype was scored as susceptible.

INOCULATION STRUCTURE TESTS. Potted seedling trees of eight progenies (05023, 05024, 06027, 06028, 09029, 09030, 09031, and 09032) were placed under the inoculation structure at the OSU Smith Horticulture Research Farm from March to June during the years 2007, 2008, and 2011, 2 years after the crosses were made. The seedlings were grown in the greenhouse their first year, and moved to the EFB structure when dormant. Potted trees of 'Ennis' (highly susceptible) and 'Tonda di Giffoni' (high quantitative resistance) were placed under the inoculation structure with the seedlings as controls in the 2008 and 2011 exposures, but only seedlings were exposed in 2007. The inoculation structure was composed of a wooden frame supporting wire mesh platforms over the trees, as described by Pinkerton et al. (1993). Hazelnut branches bearing cankers with stromata from $A$. anomala were collected from the OSU Smith Horticulture Research Farm and placed on the mesh above the plants. Irrigation sprinklers installed above the mesh and inoculum were turned on daily beginning at leaf budbreak for a total of $60 \mathrm{~min}$ each morning to ensure branch wetness and spore discharge. After the seedling trees were exposed, they were transplanted to nursery rows. Structure-inoculated trees were scored for disease response 18 months after exposure. Seedlings were observed for the presence of cankers and stromata, and disease severity was scored on a scale of 0 to 5 , with 0 being absence of disease symptoms and 5 being very severe disease symptoms. For clonal selections, $\approx 12$ potted trees of each were exposed, and total numbers of cankers per tree were recorded along with the length of each canker.

Data Analysis. Counts of susceptible and resistant seedlings were tallied in each progeny, and the observed ratios were compared with the 1:1 segregation ratio expected for a single locus and a heterozygous resistant parent using a chi-square goodness-of-fit test (Table 2). A test of heterogeneity was also performed for progenies that shared the same resistance source, to determine if the data from the progenies could be pooled for analysis.

DNA EXtraction. DNA was extracted from parents and seedlings inoculated in the greenhouse and from some seedlings inoculated under the structure (Table 1). Whole-genome DNA was extracted from the three resistant parents, four susceptible parents, and seedlings in five progenies (Table 1). DNA was extracted from fresh, young leaves collected in the spring. DNA extraction followed the protocol of Lunde et al. (2000) with no RNAase treatment. DNA was quantified by a BioTek Synergy 2 microplate reader paired with Gen5 data analysis software (BioTek Instruments, Winooski, VT) and diluted with Tris-EDTA buffer to a concentration of $20 \mathrm{ng} \cdot \mathrm{mL}^{-1}$.

Screening With DNA MARKers. The resistant parents 'Culplà', 'Crvenje', and OSU 495.072 were screened using the polymerase chain reaction (PCR) and the RAPD primers UBC268 and UBC152, which generate markers linked to 'Gasaway' resistance. PCR was performed as described by Mehlenbacher et al. (2004). 'Gasaway', 'Jefferson', and OSU 414.062, which contain the 'Gasaway' resistance gene, were

Table 2. Disease response following inoculation with Anisogramma anomala in hazelnut progenies segregating for resistance from 'Culplà', 'Crvenje', and OSU 495.072.

\begin{tabular}{|c|c|c|c|c|c|c|c|}
\hline \multirow[b]{2}{*}{ Progeny } & \multirow[b]{2}{*}{ Parents } & \multicolumn{2}{|c|}{ Plants (no.) } & \multirow{2}{*}{$\begin{array}{l}\text { Expected } \\
\text { ratio }\end{array}$} & \multicolumn{3}{|c|}{ Chi-square } \\
\hline & & Resistant & Susceptible & & Value & df & $\mathrm{P}$ \\
\hline 05024 & OSU $675.028 \times$ Culplà & 60 & 57 & $1: 1$ & 0.08 & 1 & 0.78 \\
\hline 05023 & OSU $612.015 \times$ Culplà & 69 & 23 & $3: 1$ & 0.00 & 1 & 1.00 \\
\hline Pooled data & & 129 & 80 & $1: 1$ & 11.49 & 1 & $<0.001$ \\
\hline Heterogeneity & & & & & 11.59 & 1 & $<0.001$ \\
\hline \multicolumn{8}{|c|}{ Resistance from Crvenje } \\
\hline 06027 & OSU $675.028 \times$ Crvenje & 103 & 134 & $1: 1$ & 4.06 & 1 & 0.04 \\
\hline 06028 & Crvenje $\times$ OSU 679.114 & 40 & 60 & $1: 1$ & 4.00 & 1 & 0.05 \\
\hline Pooled data & & 143 & 194 & $1: 1$ & 7.72 & 1 & 0.01 \\
\hline Heterogeneity & & & & & 0.34 & 1 & 0.56 \\
\hline 09030 & OSU $1136.051 \times$ OSU 1041.069 & 31 & 38 & $1: 1$ & 0.71 & 1 & 0.40 \\
\hline 09031 & OSU $1154.027 \times$ OSU 1029.039 & 22 & 30 & $1: 1$ & 1.23 & 1 & 0.27 \\
\hline 09032 & OSU $1154.027 \times$ OSU 1039.051 & 13 & 10 & $1: 1$ & 0.39 & 1 & 0.53 \\
\hline Pooled data & & 206 & 154 & $1: 1$ & 3.00 & 1 & 0.08 \\
\hline Heterogeneity & & & & & 11.57 & 4 & 0.02 \\
\hline
\end{tabular}

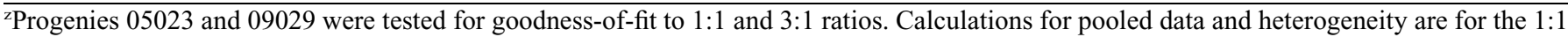
ratio. 
included as checks. PCR products were separated by electrophoresis on $2 \%$ agarose gels, stained with ethidium bromide (Sigma-Aldrich, St. Louis, MO) and imaged under ultraviolet light using a BioDoc-It ${ }^{\circledR}$ Imaging System (UVP, Upland, CA). Presence of a 580-bp band amplified by primer UBC268 and an $800 \mathrm{bp}$ band amplified by UBC152 indicates presence of the 'Gasaway' resistance gene. To assign EFB resistance from the new sources to a LG, sets of 32 seedlings plus the two parents of progenies 01035, 05024, and 06027 were amplified with microsatellite primer pairs. A set of 24 microsatellite markers that had been previously mapped was selected to investigate correlation with resistance (Mehlenbacher et al., 2006). The selected markers were distributed across the genome, with markers representing each LG. The PCR mix was a total of $10 \mu \mathrm{L}$ per reaction and contained $0.3 \mu \mathrm{M}$ each of the fluorescentlabeled forward and nonfluorescent reverse primer, $1 \times$ Biolase $\mathrm{NH}_{4}$ reaction buffer, $2 \mathrm{~mm} \mathrm{MgCl} 2,200 \mu \mathrm{M}$ each of dATP, dTTP, $\mathrm{dGTP}$, and $\mathrm{dCTP}, 20 \mathrm{ng}$ template DNA, and 0.25 units of Biolase DNA polymerase (Bioline USA, Boston, MA). Ninety-six reactions were run simultaneously on GeneAmp PCR System 9700 (Applied Biosystems, Foster City, CA) and MyCycler (Bio-Rad, Hercules, CA) thermal cyclers. The PCR program was: denaturation at $94{ }^{\circ} \mathrm{C}$ for $5 \mathrm{~min}$ followed by 40 cycles of $94^{\circ} \mathrm{C}$ for $40 \mathrm{~s}, 60^{\circ} \mathrm{C}$ for $40 \mathrm{~s}, 72^{\circ} \mathrm{C}$ for $40 \mathrm{~s}$, followed by $72^{\circ} \mathrm{C}$ for $7 \mathrm{~min}$ of extension and ending with an infinite hold at $4{ }^{\circ} \mathrm{C}$. PCR products from each reaction were multiplexed, with six to twelve different primer products in each multiplex set. Two microliters of each product were combined in $150 \mu \mathrm{L}$ water, and a $1-\mu \mathrm{L}$ aliquot of the mixture was submitted to the Core Laboratory facility of the Center for Genome Research and Biocomputing at OSU for genotyping with capillary electrophoresis using an ABI 3730 DNA Analyzer (Life Technologies, Carlsbad, CA). The fragment sizes were estimated with Gene Mapper ${ }^{\circledR}$ software (Life Technologies). The length of the amplified fragments was recorded for each primer pair for each seedling. Genotyping and disease response data were entered into a spreadsheet for each of the three populations. Disease response was scored as 1 if the individual was resistant and 0 if the individual was susceptible. Microsatellite markers were scored for each seedling as the presence (1) or absence (0) of that allele. A correlation coefficient for each marker and the corresponding disease response data were calculated using formulas in the spreadsheet. Coefficients with absolute values greater than 0.5 indicated the LG of the resistance gene and were investigated further.

Mapping Resistance LOCI. When correlation coefficients indicated the LG, microsatellite markers previously mapped to that $\mathrm{LG}$ were used to amplify the parents of the seedling populations. For markers that segregated in the progeny, 96 seedlings each from progenies 01035,05024 , and 06027 and 48 seedlings each from progenies 05023 and 06028 were genotyped as described above. Marker and disease response data were recoded as " $h$ " for resistance/allele present and "a" for susceptibility/allele absent, and maps constructed using Join Map 4.0 (Van Ooijen and Voorrips, 2006) using the BC1 function. Initial maps were inspected for agreement of scores for disease and adjacent SSR markers. When disease and marker scores conflicted, the disease scores were entered as " u" for unknown. Microsatellite markers located within $20 \mathrm{cM}$ of the resistance were used to construct the maps, with map distances shown in centimorgans.

\section{Results}

Following greenhouse inoculation, resistant parents 'Culplà', 'Crvenje', and OSU 495.072 consistently showed no disease symptoms, while the susceptible parents OSU 675.028, OSU 612.015, and OSU 679.114 developed cankers. Cankers were observed on all trees of the susceptible control 'Ennis', but on only 12 of 17 trees of 'Tonda di Giffoni', which has quantitative resistance. OSU 713.068 did not show disease symptoms when it was inoculated in 2005, but that year's inoculations resulted in many escapes, and it is presumed to be susceptible (S.A. Mehlenbacher, unpublished data), as are both of its parents. The RAPD markers UBC268 ${ }_{580}$ and UBC152 800 were absent in 'Culplà', 'Crvenje', and OSU 495.072 but present in the positive checks 'Gasaway', 'Jefferson', and OSU 414.062 (Fig. 2). These results suggest that the resistance in 'Culplà', 'Crvenje', and OSU 495.072 is different from 'Gasaway'.

Disease response scores and segregation ratios were tallied for the nine progenies (Table 2). Seedlings were classified as resistant or susceptible; none showed intermediate ratings. Of the two 'Culplà' progenies, 05024 segregated 1:1 as expected, but 05023 showed a surplus of resistant seedlings and fit a 3:1 segregation ratio. The 'Crvenje' progenies 06027 and 06028 did not fit the expected 1:1 but had an excess of susceptible seedlings. Progeny 01035 , which segregates for resistance from OSU 495.072, has more resistant than susceptible seedlings, and it does not fit either a 1:1 or 3:1 segregation ratio. Of the four additional progenies segregating for resistance from OSU 495.072, three (09030, 099031, and 09032) showed good fit to

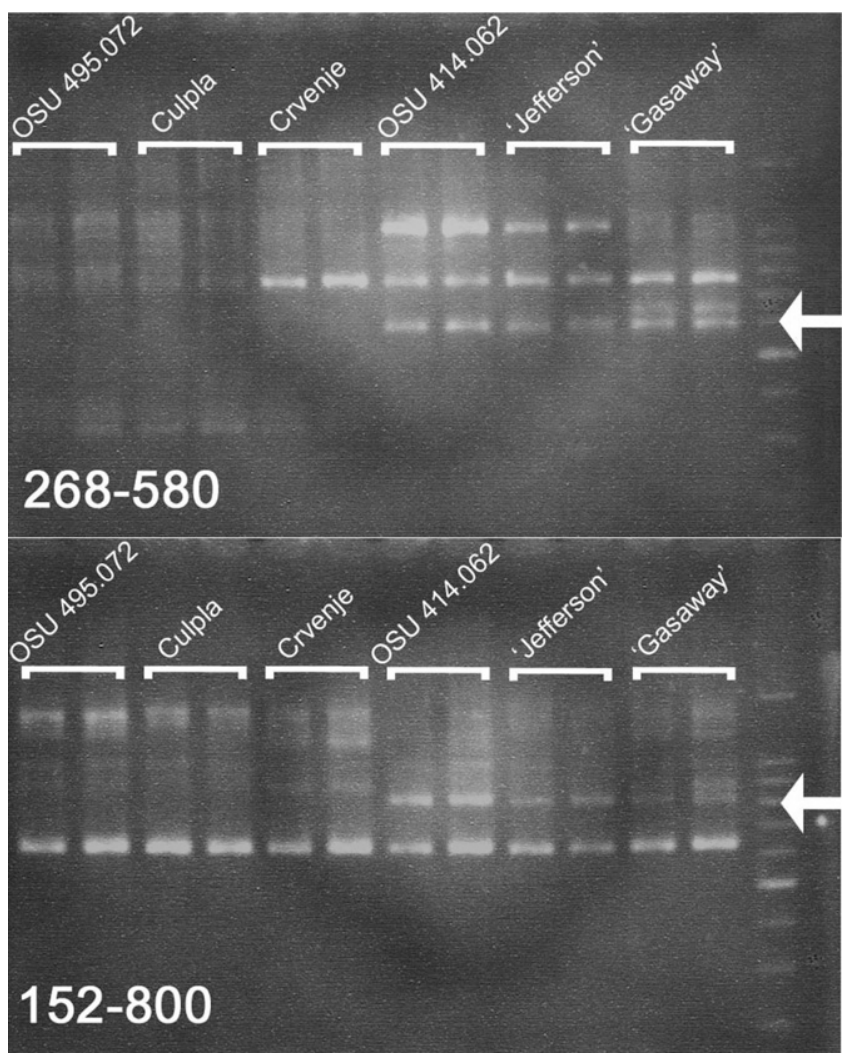

Fig. 2. Agarose gel showing that RAPD markers UBC268 580 and $\mathrm{UBC} 152_{800}$ are present in three hazelnut genotypes with EFB resistance from 'Gasaway' but absent in 'Culplà', 'Crvenje' and OSU 495.072. 
a 1:1 ratio, while progeny 09029 had an excess of resistant seedlings and showed better fit to a 3:1 segregation. All trees of the susceptible checks 'Daviana' and 'Ennis' in the 2008 exposure and 'Barcelona' in the 2011 exposure developed cankers, while for 'Tonda di Giffoni', 1 of 4 and 9 of 9 developed cankers, respectively.

Microsatellite markers correlated $(|r|>0.5)$ with resistance were found for 'Culplà', 'Crvenje', and OSU 495.072. Scores for marker A614 were correlated with resistance from all three resistant parents. The correlation coefficients of this marker were 0.62 for 'Culplà', 0.71 for 'Crvenje' and 0.63 for OSU 495.072. A614 had previously been mapped to LG6 (Gürcan et al., 2010), indicating that all three resistance loci were on LG6. Ninety-six seedlings of progenies 01035, 05024, and 06027 and 48 seedlings of progenies 05023 and 06028 were fingerprinted with segregating microsatellite markers from LG6, giving five maps, of which three are presented (Fig. 3). Disease scores were recorded for 98 additional seedlings in these three progenies, but they were not fingerprinted with LG6 microsatellite markers. Marker and disease phenotype segregation for the fingerprinted genotypes were fairly consistent, with some exceptions. In 'Culplà' progeny 05024, two individuals scored as resistant had SSR markers indicating susceptibility, and one individual scored as susceptible showed marker data consistent with resistant phenotypes. The second 'Culplà' progeny 05023 similarly had two resistant and one susceptible tree that conflicted with marker data. 'Crvenje' progeny 06027 had four resistant and four susceptible individuals whose disease scores conflicted with the marker data, while the second 'Crvenje' progeny 06028 had one susceptible individual with a score that conflicted with the DNA marker data. Progeny 01035, segregating for resistance from OSU 495.072, had one resistant and two susceptible seedlings whose disease scores conflicted with the scores of adjacent SSR markers. Disease scores for these 18 seedlings were reentered as " $\mathrm{u}$ " for unknown, and final maps generated.

For all three sources, the resistance loci were mapped to LG6. A map was constructed for each of three progenies ( 96 seedlings each of 01035, 05024, and 06027) and aligned with the reference map for a population segregating for 'Gasaway' resistance (Mehlenbacher et al., 2006) with additional SSR markers added by Sathuvalli and Mehlenbacher (2013). SSR markers closely linked to resistance were found for all three sources. The 'Culplà' resistance locus is closely linked to LG628, LG637, LG682, LG687, and LG688. The map for progeny $05023(n=48$, not shown) aligned with that of progeny 05024. The 'Crvenje' resistance locus is closely linked to LG628, LG639, LG648, LG675, and LG696. The map for progeny 06028 ( $n=48$, not shown) aligned with that of progeny 06027. And the OSU 495.072 resistance is closely linked to LG637, LG639, LG648, LG 668, LG687, and LG696 in progeny 01035.

\section{Discussion}

'Culplà', 'Crvenje', and OSU 495.072 have exhibited very high resistance to $A$. anomala in multiple trials in Oregon and

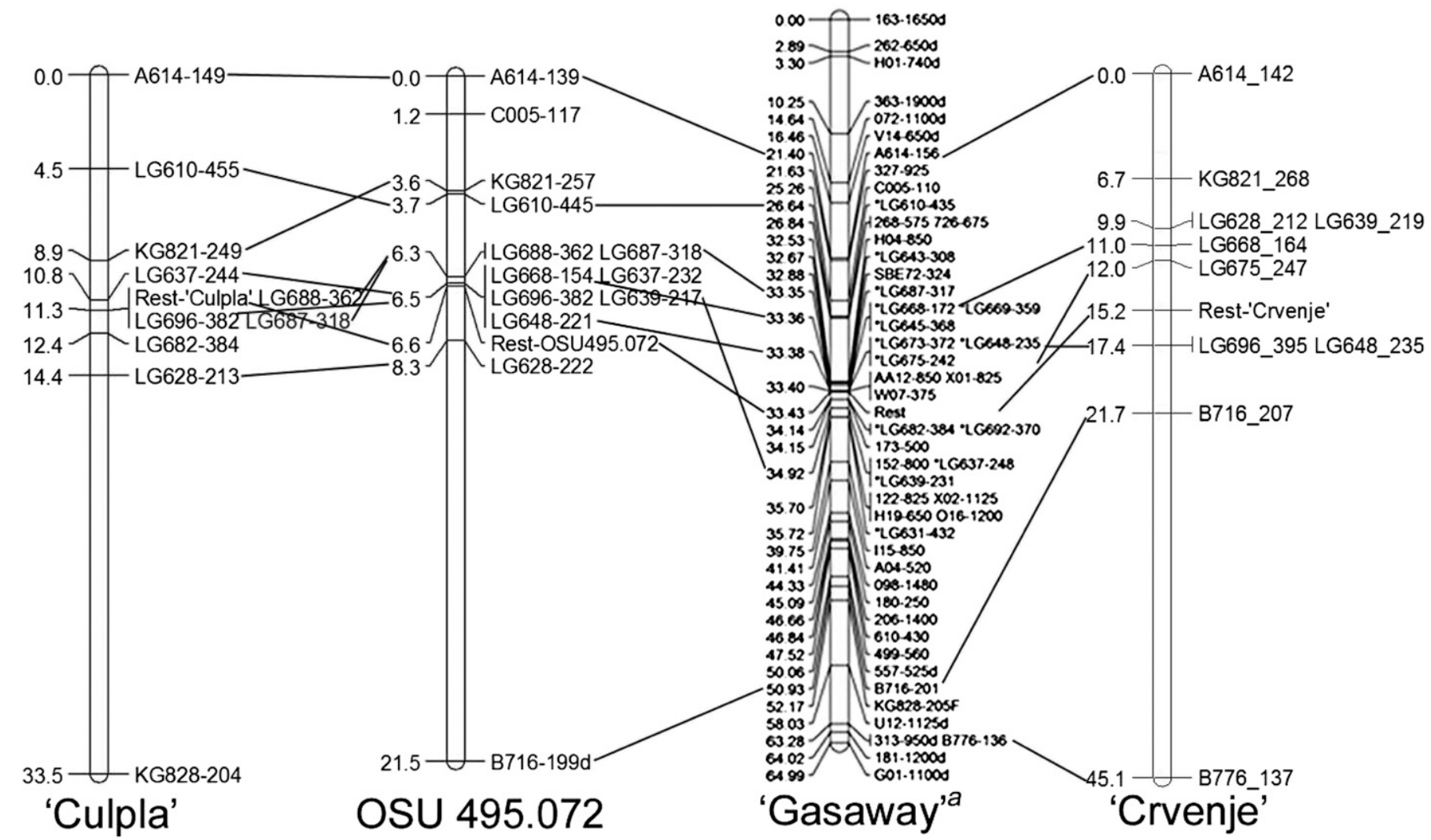

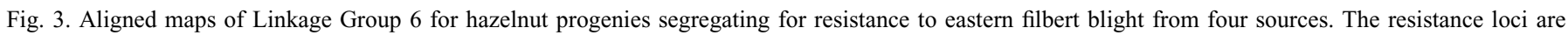
indicated as "Rest" for 'Culplà' (progeny 05024, $\mathrm{n}=96$ ), OSU 495.072 (progeny 01035, $\mathrm{n}=96$ ) and 'Crvenje' (progeny 06027, $\mathrm{n}=96$ ). The reference map of Mehlenbacher et al. (2006) is for a population that segregates for resistance from 'Gasaway' and includes the SSR markers of Sathuvalli and Mehlenbacher (2013). Lines connect the "Rest" loci in the four progenies to show their very similar positions but this does not imply that they are identical. 
New Jersey (Capik and Molnar, 2012; Chen et al., 2007; Molnar et al., 2010; Sathuvalli et al., 2010). The absence of RAPD markers UBC $268_{580}$ and UBC $152_{800}$ suggests that they do not carry the 'Gasaway' resistance gene, but rather that they are novel. All nine progenies segregated for disease response, and the proportion of resistant seedlings ranged from $40 \%$ to $75 \%$. If resistance is controlled by a single locus and is dominant, and the resistant parent is heterozygous, a ratio of 1 resistant: 1 susceptible is expected. Previous studies showed that progenies segregating for EFB resistance from 'Gasaway', 'Ratoli' and OSU 408.040 fit the 1:1 ratio. However, all 19 progenies segregating for 'Zimmerman' resistance had a surplus of resistant seedlings, and the ratio fit a 3:1 ratio for 17 of them (Lunde et al., 2006). In a study of resistance from Georgian selection OSU 759.010, Sathuvalli et al. (2011b) found that one progeny segregated $1: 1$ while a second progeny segregated $3: 1$, and that the Georgian selection was the female parent of both. In this study, only five of the nine progenies fit the $1: 1$ expectation. One 'Culplà' progeny (05024) showed good fit to the $1: 1$ ratio, but the second 'Culplà' progeny (05023) showed a ratio of 3 resistant: 1 susceptible. 'Culplà' is the male parent of both progenies. The 'Crvenje' progenies (06026 and 06028) showed a deficiency of resistant seedlings, with $58 \%$ being susceptible. 'Crvenje' is the male parent of both progenies. Of the OSU 495.072 progenies, two (01035 and 09029) showed 60\% and $68 \%$ resistant seedlings, while the remaining three fit the 1:1 ratio. The female parent of all five progenies is EFB-resistant.

It is suspected that chromosomal abnormalities are causing the skewed segregation ratios. Reciprocal translocations have been reported as common in widely grown cultivars, including Barcelona and Tonda Gentile delle Langhe (Salesses, 1973; Salesses and Bonnet, 1988), as indicated by the presence of quadrivalents or trivalents at meiosis. 'Barcelona' and 'Tonda Gentile delle Langhe' appear often in the pedigrees (Fig. 1) of the progenies in this study. If any of the parents are heterozygous for a reciprocal translocation that involves LG6, then resistance could be transmitted to more or less than the expected $50 \%$ of the gametes. Cytogenetic abnormalities typically have a larger effect on the male gametes, as pollen grains missing a chromosome arm are often inviable. Female gametes tend to be more tolerant of chromosomal abnormalities. Low pollen fertility is typical of many hazelnut cultivars (Salesses and Bonnet, 1988) and selections. There are five progenies $(01035,05023,06027,06028$, and 09029) that do not exhibit the expected 1:1 ratio of resistant to susceptible, and two of these progenies have resistance contributed by the female parent. Lunde et al. (2006) and Sathuvalli et al. (2011b) also noted deviation from the expected $1: 1$ ratio in seedlings of 'Zimmerman' and Georgian OSU 759.010, respectively. SSR markers indicate that 'Zimmerman' is a hybrid of 'Barcelona' and 'Gasaway' (Gökirmak et al., 2009), but because of cytogenetic abnormalities, Lunde et al. (2006) proposed that 'Zimmerman' inherited two copies of the chromosome region that contains the resistance locus and flanking RAPD markers. If the region containing the resistance were attached to two independent centromeres, a 3:1 segregation ratio for disease response and flanking markers would be expected. In two progenies segregating for EFB resistance from Georgian OSU 759.010, Sathuvalli et al. (2011b) found that one progeny fit a 1:1 ratio while the other fit a 3:1 ratio. Georgian OSU 759.010 was the female parent of both progenies. In spite of the aberrant ratios, resistance and flanking markers were mapped to LG2. In our study, resistance from 'Culplà', 'Crvenje', and OSU 495.072 mapped to LG6.

Disease scores for 18 seedlings conflicted with the scores for adjacent SSR markers. For these, disease scores were reentered as " $u$ " for unknown, and final maps generated. For the nine seedlings scored as resistant but marker data indicates susceptibility, it is likely that the individuals escaped infection from $A$. anomala by chance. For the nine inoculated seedlings scored as susceptible but marker data indicate that the individual should have a resistant phenotype, an explanation is more difficult. With 'Gasaway' resistance, it is possible for the resistance gene to be present and for the tree to sometimes develop a few small cankers (S.A. Mehlenbacher, unpublished data). Under high disease pressure in the field, small cankers have been observed on 'Jefferson' and 'McDonald', both of which carry 'Gasaway' resistance. This type of mismatch (i.e., resistant seedlings with small cankers) was observed in populations segregating for resistance from 'Zimmerman' (Lunde et al., 2006), and in both that study and this, the number of mismatches is small. Another possibility is that a mistake was made during DNA extraction or amplification, or disease phenotype scoring.

The resistance loci of 'Culplà', 'Crvenje', and OSU 495.072 all mapped to LG6 in the same region as 'Gasaway' resistance. EFB resistance from OSU 408.040 also maps to this region on LG6 (Sathuvalli et al., 2012). It is unclear if the five resistance loci that mapped to LG6 are the same. The three parents in our study have very different geographic origins (eastern Spain, Serbia and southern Russia, respectively). 'Culpla' and OSU 495.072 were included in the germplasm characterization study of Gökirmak et al. (2009), along with previously studied EFBresistant accessions 'Gasaway', 'Zimmerman', OSU 408.040, 'Ratoli', and Georgian selection OSU 759.010 [under the designation 'Gulshishvela' (not)]. 'Crvenje' was not included in the study. Gökirmak et al. (2009) assigned most of the 198 unique accessions to one of four major groups: Central European, Black Sea, English, or Spanish-Italian. 'Gasaway' and 'Zimmerman' clustered together, as expected, OSU 495.072 appeared nearby in the dendrogram, and all were outside of the four major geographic groups. This suggests that OSU 495.072 and 'Gasaway' may be somewhat related. OSU 408.040 was also placed outside of the major groups but far from 'Gasaway'. Georgian OSU 759.010 was placed in the Black Sea group near 'Imperiale de Trebizonde'. 'Culpla' was placed in the Spanish-Italian group as was 'Ratoli'. Interestingly, 'Culplà' and 'Ratoli' originated in eastern Spain yet resistance in the former maps to LG6 and in the latter to LG7 (Sathuvalli et al., 2011a).

There have been some reports that resistance genes cluster in the genome, including those from lettuce [Lactuca sativa L. (McHale et al., 2009)], perennial ryegrass [Lolium perenne L. (Dracatos et al., 2009)], and Arabidopsis thaliana (L.) Heynh. (Field et al., 2011). There have been increasing numbers of plants found to have clusters of genes related to defense mechanisms. Even genes coding for peroxidase, a secondary metabolite involved in broad plant defense, have been observed in clusters in barley (González et al., 2010). The resistance gene clusters are thought to have arisen by duplication, genome organization, and neofunctionalization (Field et al., 2011). In hazelnut, a cluster of distinct resistance genes in the same region on LG6 could have arisen by any one of these suggested routes. To determine if these three resistance loci are the same, they could be cloned and sequenced, followed with validation of expression by real-time 
PCR to monitor gene expression following inoculation. For EFB resistance from 'Gasaway', three candidate genes have been suggested (Sathuvalli, 2011). These would be a logical starting point for such investigations.

Several microsatellite markers were found to be closely linked to the resistance loci in all five populations. Markers developed from the sequences of BACs near the 'Gasaway' resistance gene (Sathuvalli and Mehlenbacher, 2013) were especially useful. Markers LG648, LG668, LG687, and LG696 were located 1.8-2.1 cM from the resistance loci, and showed few mismatches between phenotype and marker data. In the 'Culplà' populations, markers LG628, LG637, and LG682 also mapped within $1.1 \mathrm{cM}$ of the resistance. The two 'Crvenje' populations also had some of the same markers closely linked to resistance: LG648, LG675, and LG696. All of these markers are potentially useful for MAS. To date, 'Gasaway' has been used extensively in breeding programs as a source of EFB resistance. 'Yamhill', 'Jefferson', 'Dorris', 'Wepster', and 'McDonald' carry EFB resistance from 'Gasaway'. However, with the potential for breakdown of 'Gasaway' resistance, other sources of resistance are desirable. With the aid of linked markers, resistance from 'Culplà', 'Crvenje', and OSU 495.072 can be used to select resistant seedlings quickly, and new cultivars containing these new sources of resistance developed after one or two backcross generations.

An added benefit of identifying markers linked to disease resistance from multiple sources is that it facilitates the pyramiding of resistance genes. MAS could be used to combine two resistance genes in the same individual, which should increase the durability of resistance to $A$. anomala. This approach has been used successfully in apple (Kellerhals et al., 2009), barley (Richardson et al., 2006), and rice (Huang et al., 1997). With markers linked to resistance in 'Gasaway' (Mehlenbacher et al., 2004), 'Ratoli' (Sathuvalli et al., 2011a), Georgian OSU 759.010 (Sathuvalli et al., 2011b), and OSU 408.040 (Sathuvalli et al., 2012), and now 'Culplà', 'Crvenje', and OSU 495.072, there is great potential to pyramid these resistance genes in hazelnut.

'Culplà', 'Crvenje', and OSU 495.072 are promising sources of resistance to $A$. anomala. 'Culplà' has a small tree canopy and round nuts borne in clusters of three to five in hirsute, slit husks. 'Crvenje' has a moderate to large tree canopy and small, slightly oblong nuts borne in clusters of one or two in long, fringed husks. OSU 495.072 has a moderate tree canopy size and very small, slightly long and pointed nuts, which are borne in clusters of two to four in long, slit husks. While all three have some undesirable traits including small nut size, a modified backcross approach would combine disease resistance with other desirable traits. 'Gasaway' has very small nuts and very low nut yield. 'Santiam' and 'Yamhill' were released from the first backcross generation (Mehlenbacher et al., 2007, 2009), and 'Jefferson', 'Dorris', 'Wepster', 'McDonald' and pollenizers 'Eta', 'Theta', 'York' and 'Felix' from the second backcross generation (Mehlenbacher et al., 2011, 2012; S.A. Mehlenbacher, unpublished). Microsatellite markers linked to resistance in 'Culplà'. 'Crvenje', and OSU 495.072 will be useful for introgression of the resistance genes from these selections.

\section{Literature Cited}

Bassil, N.V., R. Botta, and S.A. Mehlenbacher. 2005. Microsatellite markers in hazelnut: Isolation, characterization and cross-species amplification. J. Amer. Soc. Hort. Sci. 130:543-549.
Boccacci, P. and R. Botta. 2010. Microsatellite variability and genetic structure in hazelnut (Corylus avellana L.) cultivars from different growing regions. Sci. Hort. 124:128-133.

Boccacci, P., A. Akkak, N.V. Bassil, S.A. Mehlenbacher, and R. Botta. 2005. Characterization and evaluation of microsatellite loci in european hazelnut (Corylus avellana L.) and their transferability to other Corylus species. Mol. Ecol. Notes 5:934-937.

Cameron, H.R. 1976. Eastern filbert blight established in the Pacific Northwest. Plant Dis. Rptr. 60:737-740.

Capik, J.M. and T.J. Molnar. 2012. Assessment of host (Corylus sp.) resistance to eastern filbert blight in New Jersey. J. Amer. Soc. Hort. Sci. 137:157-172.

Capik, J.M., M. Muehlbauer, A. Novy, J.A. Honig, and T.J. Molnar. 2013. Eastern filbert blight-resistant hazelnuts from Russia, Ukraine and Poland. HortScience 48:466-473.

Chen, H., S.A. Mehlenbacher, and D.C. Smith. 2005. AFLP markers linked to eastern filbert blight resistance from OSU 408.040 hazelnut. J. Amer. Soc. Hort. Sci. 130:412-417.

Chen, H., S.A. Mehlenbacher, and D.C. Smith. 2007. Hazelnut accessions provide new sources of resistance to eastern filbert blight. HortScience 42:466-469.

Davis, J.W. and S.A. Mehlenbacher. 1997. Identification and development of PCR-based markers linked to eastern filbert blight resistance in hazelnut. Acta Hort. 445:553-556.

Dracatos, P.M., N.O. Cogan, T.I. Sawbridge, A.R. Gendall, K.F. Smith, G.C. Spangenberg, and J.W. Forster. 2009. Molecular characterisation and genetic mapping of candidate genes for qualitative disease resistance in perennial ryegrass (Lolium perenne L.). BMC Plant Biol. 9:62.

Field, B., A.S. Fiston-Lavier, A. Kemen, K. Geisler, H. Quesneville, and A.E. Osbourn. 2011. Formation of plant metabolic gene clusters within dynamic chromosomal regions. Proc. Natl. Acad. Sci. USA 108:16116-16121.

González, A.M., T.C. Marcel, Z. Kohutova, P. Stam, and C.G. van der Linden. 2010. Peroxidase profiling reveals genetic linkage between perosidase gene clusters and basal host and non-host resistance to rusts and mildew in barley. PLoS ONE 5(8):e10495.

Gottwald, T.R. and H.R. Cameron. 1979. Morphology and life history of Anisogramma anomala. Mycologia 71:1107-1126.

Gökirmak, T., S.A. Mehlenbacher, and N.V. Bassil. 2009. Characterization of european hazelnut (Corylus avellana) cultivars using SSR markers. Genet. Resources Crop Evol. 56:147-172.

Gürcan, K. and S.A. Mehlenbacher. 2010. Development of microsatellite marker loci for european hazelnut (Corylus avellana L.) from ISSR fragments. Mol. Breed. 26:551-559.

Gürcan, K., S.A. Mehlenbacher, R. Botta, and P. Boccacci. 2010. Development, characterization, segregation, and mapping of microsatellite markers for european hazelnut (Corylus avellana L.) from enriched genomic libraries and usefulness in genetic diversity studies. Tree Genet. Genomes 6:513-531.

Huang, N., E.R. Angeles, J. Domingo, G. Magpantay, S. Singh, G. Zhang, N. Kumaravadivel, J. Bennett, and G.S. Khush. 1997. Pyramiding of bacterial blight resistance genes in rice: Marker-assisted selection using RFLP and PCR. Theor. Appl. Genet. 95:313-320.

Johnson, K.B., S.A. Mehlenbacher, J.K. Stone, and J.W. Pscheidt. 1996. Eastern filbert blight of european hazelnut: It's becoming a manageable disease. Plant Dis. 80:1308-1316.

Kellerhals, M., T. Szekely, C. Sauer, J.E. Frey, and A. Patocchi. 2009. Pyramiding scab resistance in apple breeding. Erwerbs-Obstbau 51:21-28.

Lunde, C.F., S.A. Mehlenbacher, and D.C. Smith. 2000. Survey of hazelnut cultivars for response to eastern filbert blight inoculation. HortScience 35:729-731.

Lunde, C.F., S.A. Mehlenbacher, and D.C. Smith. 2006. Segregation for resistance to eastern filbert blight in progeny of 'Zimmerman' hazelnut. J. Amer. Soc. Hort. Sci. 131:731-737.

McDonald, B.A. and C. Linde. 2002. The population genetics of plant pathogens and breeding strategies for durable resistance. Euphytica 124:163-180. 
McHale, L.K., M.J. Truco, A. Kozik, T. Wroblewski, O.E. Ochoa, K.A. Lahre, S.J. Knapp, and R.W. Michelmore. 2009. The genomic architecture of disease resistance in lettuce. Theor. Appl. Genet. 118:565-580.

Mehlenbacher, S.A. 1995. Classical and molecular approaches to breeding fruit and nut crops for disease resistance. HortScience 30:466-477.

Mehlenbacher, S.A. and J. Olsen. 1997. The hazelnut industry in Oregon, USA. Acta Hort. 445:337-345.

Mehlenbacher, S.A., M.M. Thompson, and H.R. Cameron. 1991. Occurrence and inheritence of resistance to eastern filbert blight in 'Gasaway' hazelnut. HortScience 26:410-411.

Mehlenbacher, S.A., R.N. Brown, J.W. Davis, H. Chen, N.V. Bassil, D.C. Smith, and T.L. Kubisiak. 2004. RAPD markers linked to eastern filbert blight resistance in Corylus avellana. Theor. Appl. Genet. 108:651-656.

Mehlenbacher, S.A., R.N. Brown, E.R. Nouhra, T. Gökirmak, N.V. Bassil, and T.L. Kubisiak. 2006. A genetic linkage map for hazelnut (Corylus avellana L.) based on RAPD and SSR markers. Genome 49:122-133.

Mehlenbacher, S.A., A.N. Azarenko, D.C. Smith, and R.L. McCluskey. 2007. 'Santiam' hazelnut. HortScience 42:715-717.

Mehlenbacher, S.A., D.C. Smith, and R.L. McCluskey. 2009. 'Yamhill' hazelnut. HortScience 44:845-847.

Mehlenbacher, S.A., D.C. Smith, and R.L. McCluskey. 2011. 'Jefferson' hazelnut. HortScience 46:662-664.

Mehlenbacher, S.A., D.C. Smith, and R.L. McCluskey. 2012. 'Eta' and 'Theta' hazelnut pollenizers. HortScience 47:1180-1181.

Molnar, T.J., J.C. Goffreda, and C.R. Funk. 2010. Survey of Corylus resistance to Anisogramma anomala from different geographic locations. HortScience 45:832-836.

Muehlbauer, M.F., J.A. Honig, J.M. Capik, J.N. Vaiciunas, and T.J. Molnar. 2014. Characterization of eastern filbert blight-resistant hazelnut germplasm using microsatellite markers. J. Amer. Soc. Hort. Sci. 139:399-432.

Peterschmidt, B.C. 2013. DNA markers and characterization of novel sources of eastern filbert blight resistance in european hazelnut (Corylus avellana L.). M.S. Thesis, Oregon State Univ., Corvallis, OR.

Pinkerton, J.N., K.B. Johnson, K.M. Theiling, and J.A. Griesbach. 1992. Distribution and characteristics of the eastern filbert blight epidemic in western Oregon. Plant Dis. 76:1179-1182.

Pinkerton, J.N., K.B. Johnson, S.A. Mehlenbacher, and J.W. Pscheidt. 1993. Susceptibility of european hazelnut clones to eastern filbert blight. Plant Dis. 77:261-266.

Pinkerton, J.N., K.B. Johnson, J.K. Stone, and K.L. Ivors. 1998a. Maturation and seasonal discharge pattern of ascospores of Anisogramma anomala. Phytopathology 88:1165-1173.
Pinkerton, J.N., K.B. Johnson, J.K. Stone, and K.L. Ivors. 1998 b. Factors affecting the release of ascospores of Anisogramma anomala. Phytopathology 88:122-128.

Richardson, D.G. 1997. The health benefits of eating hazelnuts: Implications for blood lipid profiles, coronary heart disease and cancer risks. Acta Hort. 445:295-300.

Richardson, K.L., M.I. Vales, J.G. Kling, C.C. Mundt, and P.M. Hayes. 2006. Pyramiding and dissecting disease resistance QTL to barley stripe rust. Theor. Appl. Genet. 113:485-495.

Salesses, G. 1973. Étude cytologique du genre Corylus. Mise en évidence d'une translocation hétérozygote chez quelques variétés de noisetier cultivé ( $C$. avellana) a fertilité pollinique réduite. Annales de l'Amélioration des Plantes 23:59-66.

Salesses, G. and A. Bonnet. 1988. Etude cytogénétique d'hybrides entre variétés de noisetier (Corylus avellana) porteuses d'une translocation à l'état heterozygote. Cytologia (Tokyo) 53:407-413.

Sathuvalli, V.R. 2011. Eastern filbert blight in hazelnut (Corylus avellana): Identification of new resistance sources and high resolution genetic and physical mapping of a resistance gene. PhD Diss., Oregon State Univ., Corvallis, OR.

Sathuvalli, V.R. and S.A. Mehlenbacher. 2013. De novo sequencing of hazelnut bacterial artificial chromosomes (BACs) using multiplex Illumina sequencing and targeted marker development for eastern filbert blight resistance. Tree Genet. Genomes 9:1109-1118.

Sathuvalli, V.R., S.A. Mehlenbacher, and D.C. Smith. 2010. Response of hazelnut accessions to greenhouse inoculation with Anisogramma anomala. HortScience 45:1116-1119.

Sathuvalli, V.R., H. Chen, S.A. Mehlenbacher, and D.C. Smith. 2011a. DNA markers linked to eastern filbert blight resistance in 'Ratoli' hazelnut (Corylus avellana L.). Tree Genet. Genomes 7:337-345.

Sathuvalli, V.R., S.A. Mehlenbacher, and D.C. Smith. 2011b. DNA markers linked to eastern filbert blight resistance from a hazelnut selection from the Republic of Georgia. J. Amer. Soc. Hort. Sci. 136:350-357.

Sathuvalli, V.R., S.A. Mehlenbacher, and D.C. Smith. 2012. Identification and mapping of DNA markers linked to eastern filbert blight resistance from OSU 408.040 hazelnut. HortScience 47:570-573.

Stone, J.K., K.B. Johnson, J.N. Pinkerton, and J.W. Pscheidt. 1992. Natural infection period and susceptibility of vegetative seedlings of european hazelnut to Anisogramma anomala. Plant Dis. 76:348-352.

U.S. Department of Agriculture. 2011. Nutrients in 100 grams of tree nuts and peanuts. National nutrient database for standard reference, release 27. 16 Oct. 2014. <http://ndb.nal.usda.gov/ndb/foods>.

U.S. Department of Agriculture. 2013. Oregon facts and figures. 28 Jan. 2015. <http://www.nass.usda.gov/Statistics_by_State/Oregon/ Publications/facts_and_figures/facts_and_figures.pdf $>$.

Van Ooijen, J.W. and R.E. Voorrips. 2006. JoinMap 4.0, software for the calculation of genetic linkage maps. Kyazma, Wageningen, The Netherlands. 